\title{
Assessment of Impacts of the Forest Incentive Program based on Eucalyptus Monoculture with the 'INOVA-Tec System'
}

\author{
Katia Regina Evaristo de Jesus-Hitzschky (I), Ana Paula Carraro (2) \\ Laerte Scanavaca Júnior (3)
}

\begin{abstract}
The paper and cellulose industry uses as a source of raw material wood only from harvested forests, either in one's own lands or in other people's cultivated land, through land lease agreement or forest development programs. The present work suggests the use of a method created to evaluate the impacts of technological innovations, the Inova-tec System with modifications, to evaluate the impacts of the 'Forest Incentive Program (Programa de Fomento Florestal) based on a Eucalyptus monoculture'. The method 'INOVA-Tec System' is a system that allows the analysis of: i) the scenario to develop the program, and ii) the performance evaluation of the program, through the analysis of indicators performance. With the data on hands, it is easier for the evaluator to elaborate his/her recommendation list to guarantee a proper culture management and the best impact management, in order to mitigate the potentially problematic characteristics for the environment and for the society.
\end{abstract}

Keywords: environmental impact, forest incentive, Eucalyptus, silviculture, environmental sustainability.

(I) I Ph.D in Biotechonology, Researcher at Embrapa Environment, Jaguariúna, SP. Brazil. Rodovia SP 340 km 127,5 CP 69 CEP I3820-000 Jaguariúna, SP - Fone: (55-19) 3867-874I; Fax: (55-19) 3867-8740. E-mail: katiareg@cnpma.embrapa.br

(2) B. Sc. in Forestry

(3) MSc. in Forestry 


\section{Introduction}

The Forest Sector plants all the wood it needs and, in this way, the reforestation, which did not exist in commercial scale until the 1960s, corresponds today of more than five and a half million of hectares. Therefore, Brazil, which was an importer of paper and other forest derivative materials, from the 1980s on became an exporter, that is to say, the Forest Industry was created, established and became competitive in 20 years.

The National Forest Program (Programa Nacional de Florestas - PNF) was created with the objectives to stimulate the sustainable use of native and exotic forests, to incentive reforestation, to repress illegal deforestation and predatory extraction of forest products and sub-products, to support the development of a forest base industry, and to expand the internal and external markets for forest products and sub-products (Leão, 2000).

The Brazilian environmental policy is ambiguous and confuse. Sustainable development faces resistance from several segments of society and from the State. Economical interests wrongly consider the environment conservation an obstacle to Brazil's development and growth (Vieira \& Cader 2007).

\section{Eucalyptus in Brazil}

Around 1905, the team of Dr. Edmundo Navarro de Andrade carried out several silvicultural (spacing, fertilizing, sprouting, etc.) and technological tests (durability, density, retractibility, inflection, etc.) with the most important forest species from the most traditional countries of the Forest Sector. These experiments showed that the genus Eucaliptus assembled the best silvicultural and technological characteristics for our conditions. Consequently eucalyptus became Brazil's silvicultural base and it is a worldwide reference (Leão, 2000).

In the 1960s several agencies were created and promptly started working on eucalyptus reforesting programs. With the publication of the New Brazilian Forest Code (Novo Código Florestal Brasileiro), Law N $N^{\circ}$ 4.77I, on I5th September 1965 (D.O.U. ON 16/09/65), a new public forest policy was defined (Guerra, 1995).

In 1966, the Program of Fiscal Incentives for Forestation and Reforestation was established (Programa de Incentivos Fiscais ao Florestamento e Reflorestamento - PIFFR), aiming at a creation of a strong and competitive Forest Sector, to make the country stop importing these products since the climatic and cultural conditions were favorable. The original plan predicted Sector subventions for 30 years, but in 20 years period the Sector became competitive and we stop being importers and became exporters.

The Federal Government created the so-called "priority reforestation regions" aiming at a more balanced development policy. Besides, to avoid agriculture competition, the Brazilian Forest Sector established itself in abandoned farming areas due to misuse (Leão, 2000).

\section{Forest Sector}

The Brazilian Forest Sector has an expressive contribution to the GDP (Gross Domestic Product), to the generation of taxes and to employment, besides its social and environmental contribution. In 2006, the Forest Sector was responsible for, approximately, $R \$ 8$ billions, what represents about $6 \%$ of the country's exportations. Eucalyptus generates one direct job position for each 2.3 ha of harvested forest (ABRAF, 2007; SBS, 2008).

The demand for raw-material will be intensively provided by harvested forests of short cycles and high productivity. The annual production capacity is on average $45 \mathrm{~m} 3 / \mathrm{ha} /$ year, one of the most productive of the world, while the native forests under management produce from 20 to $30 \mathrm{~m} 3 /$ ha per 30 years cycles. Therefore harvested forests will play a more and more important role in environmental services. In this context, silviculture stands out (SBS, 2008).

According to the data from the Statistic Annuary of Brazilian Association of Harvested Forest Producers (Anuário Estatístico da Associação Brasileira de Produtores de Floresta Plantada ABRAF, 2007), the total reforested area in Brazil in 2006 was $5,373,4 I 7$ ha, from which $3,549,148$ ha were eucalyptus.

The paper and cellulose industry uses as a source of raw material wood only from harvested forests, either in one's own lands or in other people's cultivated land, through land lease agreement or forest development programs. This Sector contributes to reforestation of 25 to $30 \%$ of the area of small and medium properties in Brazil (SBS, 2008).

This kind of production by forest incentive started in Brazil, effectively, at the end of the 1970s and today is quite disseminated and practiced. In some countries like The United States and Finland this has already been happening for more than 100 years (ABRAF, 2007; SBS, 2008).

\section{Forest Incentive}

The Forest Incentive Program (Programa de Fomento Florestal) is a set of projects that incentive forest plantations. These projects can be from public, private or mixed enterprises, which as- 
semble a set of incentives aiming at forest plantation in rural properties (Leão, 2000).

The projects' objectives are to work as mechanisms of social inclusion and economical-environmental development, and to claim the occupation of marginal and inactive areas in rural properties. The incentive by the private sector makes available to producers saplings, inputs, technical assistance, transfer of technology and environmental regulation, property georeferencing and crop insurance (Jorge, 2008).

According to ABRAF's data (2007), the area under development expanded from 258,006 hectares to 322 , I 38 hectares between 2005 and 2006, so corresponding to $13.3 \%$ of the harvested area of Eucalyptus and Pinus by the large companies of the Forest Sector.

Several institutions seek advantages in forest incentive programs:

- Companies: investment return as a supply of forest products on low prices, no need for capital, institutional and marketing development, improvement of the company image through social and environmental development of the region;

- Producers: utilization of inactive lands, new income source, wood for use in the property, market guaranties, new market options;

- Government: social function fulfillment through taxes, settlement of men in rural areas, employment generation and reduction of forest deficit.

The forest incentive makes small and medium producers aware of the forest's importance, hence it reduces deforestation.

\section{Characteristics of forest incentive programs}

Most of the participating forest companies comprise from small producers to large investors.

These programs provide saplings and inputs that may come from donations or advance payment. The donation usually takes place when the company does not have a contractual bond with the producer. On advance payment, there is a contractual relationship between company and producer and the value of saplings and inputs (fertilizers and pesticides) is discounted at the end of the cycle, when the company buys the wood.

The technical assistance is more effective during the first two years, when the plantation is more vulnerable, especially to ant attacks.
The contract varies among companies, in general, the incentive company has the priority on wood acquisition, therefore, if the producer has a better offer for the wood, he/she should inform the value to the company and the company decides whether to cover the offer or not. The amount of wood sold is between 95 and $97 \%$, and the rest belongs to the producer, who will determine its destination and may sell or use it in the property.

The viability of the incentive depends on the distance between the properties and the factory, which is usually $120 \mathrm{~km}$ on average and tolerates as maximum limit $300 \mathrm{~km}$. The larger the distance between the property and the factory, the larger will be the minimum reforested area accepted, which varies from 5 to $10 \mathrm{ha}$, since smaller areas can make the project unfeasible due to exploration and transportation costs that can achieve $70 \%$ of the wood cost at the factory.

The Brazilian Forest Sector is one of the few sectors that obey the legislation, thus, to make the project feasible, it is necessary to regulate the possession of rural property and to obey the forest legislation, respecting permanent protection areas (APP - área de proteção permanente) and legal reserves (reserva legal).

Incentive programs directed to small properties are more sustainable because they generate social benefits and mitigate negative environmental impacts, when compared to extensive land properties. Besides, they leave the door open to social and community actions, created by companies' social responsibility programs (Oliveira, 2003; SBS, 2008).

\section{Methodology}

\section{Inova-tec System}

The INOVA-tec System (Jesus-Hitzschky, 2007) is a method created to evaluate direct and indirect impacts of technological innovations in several areas where the impacts can be perceived: social, environmental, economical, institutional development, training, introduction of (new) technology and unexpected events. The system allows evaluating the innovation/program scope and its performance, through significance and magnitude indexes. The inclusive nature of the method allows us to use it, with adjustments, for the assessment of Programs and Projects, inclusively the "Forest Incentive Program based on Eucalyptus Monoculture" evaluated here.

The method presents general indicators organized into criteria in each evaluated area. These parameters were raised and consolidated from enquiries with experts of several areas at inperson interviews. In order to have a more reliable evaluation, it is possible to insert specific indicators, enabling an analysis 
for each case for innovations, programs or projects.

The system gives more objectivity to assessments, showing the indicators to be used and the most important components to reduce negative impacts and to optimize the resources used to implement the technology or program, in order to avoid and mitigate environmental damages.

The INOVA-tec System allows an evaluation ex-ante or ex-post the innovation is used. The evaluation ex-ante intends to diagnose its potential impacts, and it is of interest of funding and incentive agencies. While the evaluation ex-post evaluates its performance on the market and effective impacts on the environment and society, and it is interesting to supervisory and regulating agencies, technology buyer business and society in general.

\section{Decription of Inova-tec System}

The INOVA-tec System allows the evaluator to point out specific parameters for its innovation what enables an analysis of each case and consequently the use of the innovation in a responsible and reliable way. The information is organized in three tools: i) worksheet to analyze the innovation scenario (significance index); ii) worksheet to evaluate indicators assessment (magnitude index); and iii) Impact Matrix that is produced from General Impact Index. The use of INOVAtec System decreases evaluation subjectivity by working as a guide that points out the indicators that should be analyzed. In order to make its use easier this method is presented in digital format' (software Inova-tec System v.l.0.), where the three tools are connected in a way that the evaluator can fill in the data on the worksheets and automatically observe the results on tables, graphics, matrix and as a descriptive report.

Aiming to evaluate the impacts of the "Eucalyptus Forest Incentive Program" this Program was compared to agricultural plantations using data from the specialized literature; afterwards, the data were converted to the format of the Software INOVA-Tec System and inserted.

\section{Results and Discussion}

\section{Inova-tec System -Case Study of the 'Eucalyptus Forest Incentive Program'}

The assessment of program impacts is an effective mitigatory measure to face the growing challenges of environmental degra- dation and worker safety.

In order to identify the impacts related to the "Eucalyptus Forest Incentive Program", and to identify measures able to mitigate its potential adverse effects, this scientific method was used to create scenarios able to determine the scope of, e.g. environmental, social, and economical effects in this program with the potential to cause negative impacts, even before field tests were performed.

Post analysis recommendations about the way the impacts should be managed are presented here. These recommendations aim to produce a complete and effective evaluation able to guide rural producers on the possibilities of economical profits, but also to warn them about the potential negative impacts on the environment, society, farmers, etc. In the same way, this evaluation may lead companies to revise incentive contracts in order to strengthen even more the programs and the environmental and social certificates of approval claimed by these programs.

Based on data collected from literature revision it was possible to fill the worksheets out to analyze the performance of the following indicators: environmental (Table I), social (Table 2), economical (Table 3), training (Table 4), and institutional development (Table 5).

\section{Prospective Analysis - Forest Sector Scenario for the Incentive Program: Significance Index}

Based on the information taken from literature it was possible to analyze the Forest Sector Scenario for the "Forest Incentive Program based on Eucalyptus Monoculture" and from the obtained result it was possible to generate the Significance Index. This index compounds one of the variables needed to calculate the general result on the Impact Matrix.

The making of the Scenario using the Inova-tec System depends on two factors (Figure I):

i) Program Scope depends on the scope or influence of the effects of the incentive program on the forest sector, in a direct or indirect manner (environmental, human health, product or process quality, social, economical, political and legal). The sum of each one of these factors compounds the Program Scope.

In the case study of "Forest Incentive Program based on Eucalyptus Monoculture" it was possible to identify a high (3)

I Available for download at the site of “Embrapa Meio Ambiente:” http://www.cnpma.embrapa.br/forms/inova_tec.php3 
influence of the program in a direct (2) manner on "environmental, social, economical and legal areas", totalizing 24 points for these four scopes. It was also observed a high (3) influence of the program, but in an indirect (I) manner on "political" environment (totalizing 3 points for this scope). Since the fulfillment of all contractual requirements tends to strengthen the company's productive area, keep the quality standards demanded by the sector and quality certificates, consequently it also brings benefits to the "Product Quality" showing high influence in a direct manner on this scope $(\mathbf{3} / \mathbf{2}$, respectively, totalizing 6 points for this scope). It was identified a null (0) influence for Human Health area.

These values were used according to the formula cited bellow, and generated 33 points for the Program Scope. The attri- buted values are supported by these programs objectives: work as mechanisms of social inclusion and of economical-environmental development.

ii) The other moderating factor considered for the scenario analysis is the "Extension" of the program effects, that can be considered punctual (weight I), local (weight 2), regional (weight 3), national (weight 4) and international (weight 5). In the case study of the "Forest Incentive Program based on Eucalyptus Monoculture" the effects on national level were considered since the spread of its use tend to influence the whole Brazilian forest sector, generating value 4 . The application of the formula bellow to the values previously obtained generates a Significance Index equals I32.

\section{$\Sigma\left(\right.$ Scope $_{\text {ag }} X$ Influence $\left.{ }_{2.8}\right)=$ Program Scope \\ Program Scope $\mathbf{X}$ Extension $=$ Significance Index}

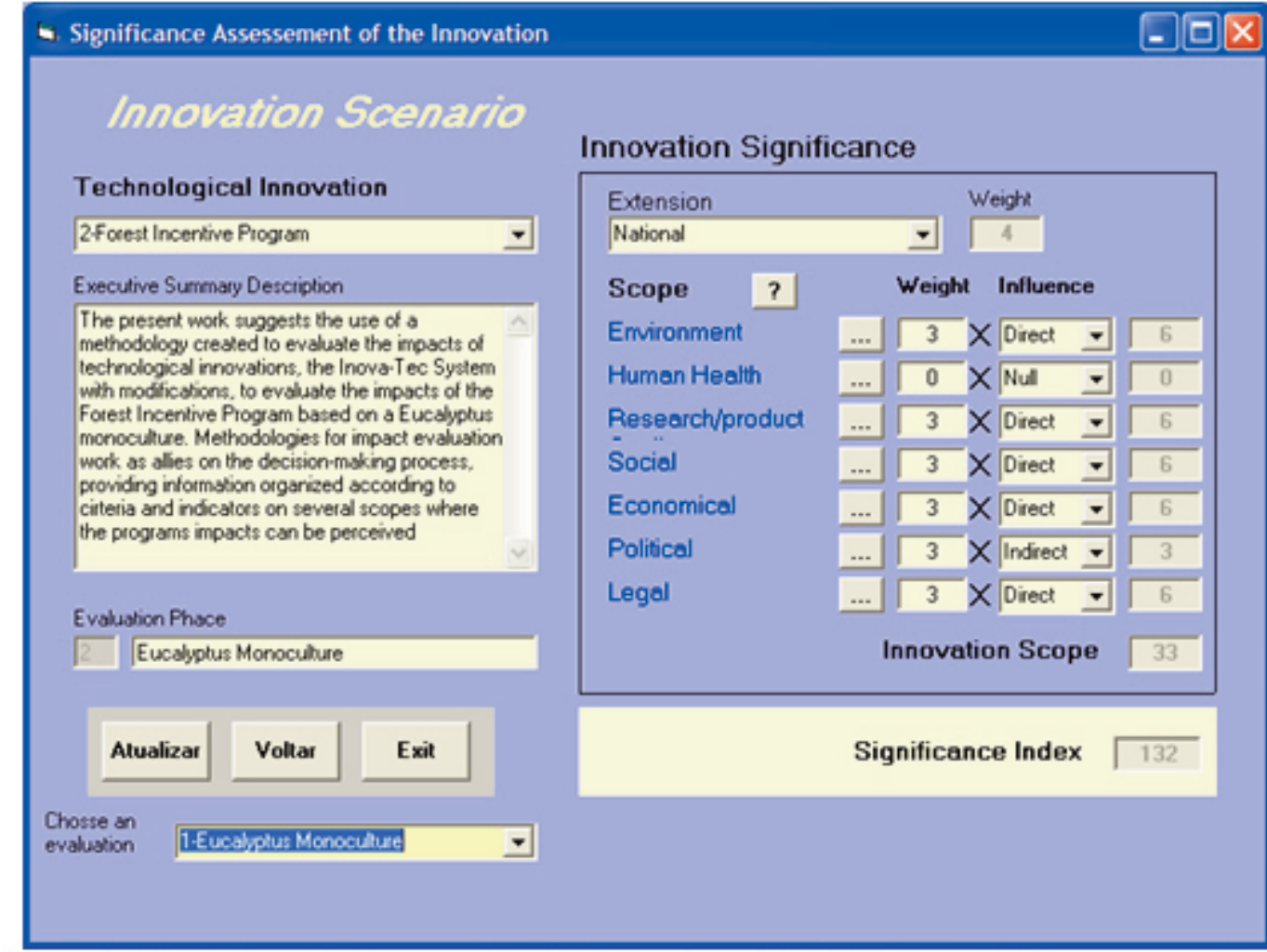

Figure I: Worksheet for Prospective Analysis - Scenario: Significance Index - case study of the "Forest Incentive Program based on Eucalyptus Monoculture". 
Impact Evaluation - Performance of the Indicators using the Magnitude Index

In order to analyze the performance of the impact indicators, firstly, it was carried out a phase of identification and consolidation of the indicators needed for impact evaluation of the program, from the indicators presented by Inova-tec System. The indicators considered irrelevant for the "Forest Incentive Program based on Eucalyptus Monoculture" evaluation were excluded from the analysis. However, specific indicators were added to the most pertinent area. These indicators are listed on
Tables I to 5 .

The tables designed to analyze the indicators' performance were filled out directly in the Software Inova-tec System v. I.0. The Software interface to analyze indicators is showed on Figure 2. The procedure of filling out this worksheet on Software format was carried out for each indicator.

The following formula was used to calculate a final value for each indicator and afterwards to calculate the General Impact Index:

\section{Indicator's Weight ${ }_{28} \times$ Weight value range ${ }_{48}+\Sigma\left(\right.$ Correction Factors $\left._{48}\right)=$ Total Indicators' Weight from Field A = Field A Total Weight $\Sigma$ (Total Weight of Fields A, B, C, D, E, F, G) / Number of Fields Analyzed = Magnitude Index (General Impact Index)}

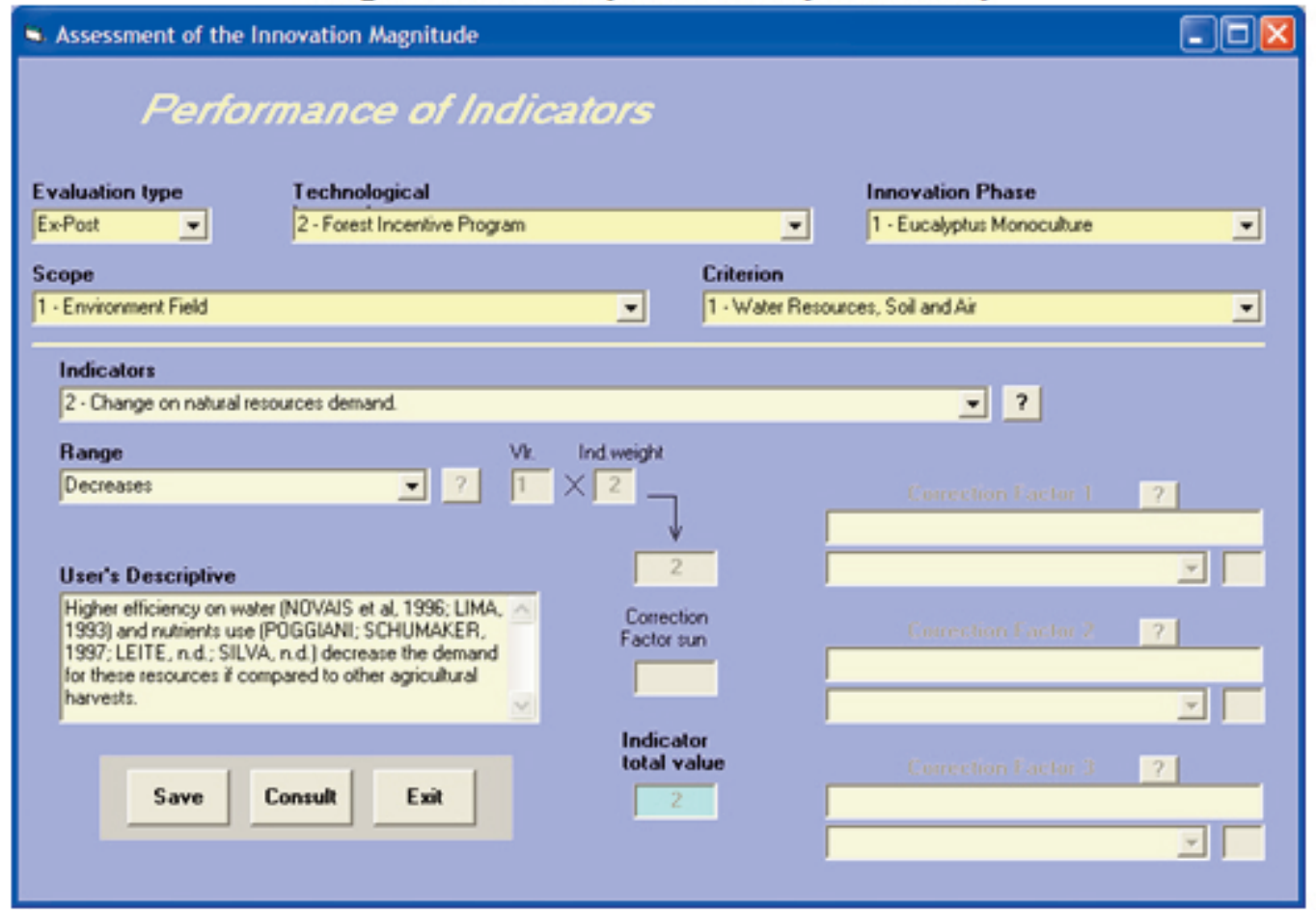

Figure 2: Worksheet to analyze the Performance of Indicators: Magnitude Index-case study of the "Forest Incentive Program based on Eucalyptus Monoculture" - Environmental Field. 
Table 1: Performance of Indicators Worksheet: Magnitude Index - Environmental Field

\begin{tabular}{|c|c|c|c|c|}
\hline \multicolumn{5}{|c|}{ Environmental Field } \\
\hline Weight & Indicator / Moderating factor & Information for Evaluation & $\begin{array}{l}\text { Weight value } \\
\text { range }\end{array}$ & $\begin{array}{l}\text { Indicator } \\
\text { value }\end{array}$ \\
\hline \multicolumn{5}{|c|}{ Water Resources, Soil and Air } \\
\hline 2 & Water quality & $\begin{array}{l}\text { Lima (1993) showed many advantages on water quality compared to agriculture and } \\
\text { livestock. The behavior is very similar to native forests; improves physical, chemical } \\
\text { and biological properties of the water. }\end{array}$ & Improves (1) & 2 \\
\hline 2 & Air pollutants emission & $\begin{array}{l}\text { Carbon sequestration is higher in plantations in growth phase. According to } \\
\text { Tsukamoto Filho (2003), in eucalyptus monocultures carbon sequestration is about } \\
58.42 \mathrm{t} / \mathrm{ha}\end{array}$ & Decreases (1) & 2 \\
\hline 2 & Chemical residues on soil & Lower need for pesticides (Poggiani, 1985; Poggiani \& Schumaker, 1997; Lima, 1993). & Decreases (1) & 2 \\
\hline 2 & Change on natural resources demand & $\begin{array}{l}\text { Higher efficiency on water (Novais, et al., 1996; Lima, 1993) and nutrients use } \\
\text { (Poggiani \& Schumaker, 1997; Leite, n.d.) decrease the demand for these resources if } \\
\text { compared to other agricultural harvests. }\end{array}$ & Decreases (1) & 2 \\
\hline \multicolumn{4}{|c|}{ TOTAL CRITERION VALUE: } & 8 \\
\hline \multicolumn{5}{|c|}{ Biological Resources: microorganisms, flora and fauna } \\
\hline 2 & Change of ecosystem balance & $\begin{array}{l}\text { Increase of flora end fauna species due to a higher diversity in consequence of lower } \\
\text { need for pesticides (Poggiani 1976, 1985). }\end{array}$ & $\begin{array}{l}\text { Does not affect } \\
(0)\end{array}$ & 0 \\
\hline 2 & $\begin{array}{l}\text { Occurrence of negative effects on } \\
\text { plants and animals }\end{array}$ & $\begin{array}{l}\text { Forests stabilize microclimate and provide a more pleasant environment, attracting } \\
\text { fauna (Poggiani 1976, 1985). }\end{array}$ & No (0) & 0 \\
\hline \multicolumn{4}{|c|}{ TOTAL CRITERION VALUE: } & 0 \\
\hline \multicolumn{5}{|c|}{ Environmental Conservation } \\
\hline 2 & $\begin{array}{l}\text { Monitoring practice or } \\
\text { environmental management. } \\
\text { Comparison between conventional } \\
\text { methods. }\end{array}$ & $\begin{array}{l}\text { Its long rotation cycle and simplicity makes it less dependent on intensive human } \\
\text { interventions compared to other harvests such as greenery, but it demands more } \\
\text { labor than orcharding or livestock, precluding the comparison between forests and } \\
\text { different systems. }\end{array}$ & Maintains (0) & 0 \\
\hline \multicolumn{4}{|c|}{ TOTAL CRITERION VALUE: } & 0 \\
\hline \multicolumn{5}{|c|}{ Environmental Recovery } \\
\hline 3 & $\begin{array}{l}\text { Provides stability to a threatened } \\
\text { ecosystem }\end{array}$ & $\begin{array}{l}\text { Maintenance or implantation of permanent protection area and compulsory legal } \\
\text { reserve through incentive contracts. }\end{array}$ & Yes (1) & 3 \\
\hline \multicolumn{4}{|c|}{ TOTAL CRITERION VALUE: } & 3 \\
\hline \multicolumn{5}{|c|}{ Environmental-specific } \\
\hline 1 & Emergence of unwanted species & A more balanced environment avoid the emergence of pests or diseases (Lima, 1993). & No (1) & 1 \\
\hline \multicolumn{4}{|c|}{ TOTAL CRITERION VALUE: } & 1 \\
\hline
\end{tabular}




\begin{tabular}{|c|c|c|c|c|c|c|}
\hline \multicolumn{7}{|c|}{ Social Field } \\
\hline Weight & Indicator / Moderating factor & \multicolumn{2}{|l|}{ Information for Evaluation } & Weight value range & \multicolumn{2}{|l|}{ Indicator value } \\
\hline \multicolumn{7}{|c|}{ Work Relationships } \\
\hline 3 & $\begin{array}{l}\text { Influence on work conditions } \\
\text { (Occupational safety and health - } \\
\text { OSH) }\end{array}$ & \multicolumn{2}{|c|}{$\begin{array}{l}\text { Compulsory use of safety equipment, respecting work legislation and } \\
\text { environment required by ISO } 14000 \text { Certification guarantees better work } \\
\text { conditions. }\end{array}$} & Improves $(+1)$ & \multicolumn{2}{|l|}{3} \\
\hline 3 & Creation of work positions. & \multicolumn{2}{|c|}{$\begin{array}{l}\text { The Forest Sector employs one worker for each } 2.3 \text { ha of forest, livestock } \\
\text { employs one worker for each } 10 \text { ha and orcharding one worker for each } 2 \\
\text { ha. However, this is not taken into consideration to decide on the } \\
\text { adoption of the system or not, precluding the comparison between forests } \\
\text { and different systems. }\end{array}$} & Does not occur $(0)$ & \multicolumn{2}{|l|}{0} \\
\hline \multicolumn{5}{|c|}{ TOTAL CRITERION VALUE } & \multicolumn{2}{|l|}{3} \\
\hline \multicolumn{7}{|c|}{ Social-Specific } \\
\hline 1 & $\begin{array}{l}\text { Income generation through } \\
\text { programs of Forest Incentive }\end{array}$ & \multicolumn{2}{|l|}{$\begin{array}{l}\text { Important amount of familiar income for producers. Usually eucalyptus } \\
\text { pays better than any other harvest (Oliveira, et al., 2000). }\end{array}$} & Yes (1) & \multicolumn{2}{|l|}{1} \\
\hline 1 & $\begin{array}{l}\text { Possibility of product } \\
\text { diversification }\end{array}$ & \multicolumn{2}{|l|}{$\begin{array}{l}\text { The development of other activities and the improvements on the } \\
\text { property outcome from generated income (Oliveira, et al., 2000). }\end{array}$} & Yes (1) & \multicolumn{2}{|l|}{1} \\
\hline 1 & Pressure on food production & \multicolumn{2}{|l|}{ Decrease of food producing area (Koopmans, 2006). } & Yes (-1) & \multicolumn{2}{|l|}{-1} \\
\hline \multicolumn{5}{|c|}{ TOTAL CRITERION VALUE: } & \multicolumn{2}{|l|}{1} \\
\hline \multicolumn{5}{|c|}{ TOTAL FIELD VALUE } & \multicolumn{2}{|l|}{4} \\
\hline \multicolumn{7}{|c|}{ Table 3: Performance of Indicators W orksheet: Magnitude Index - Economical Field. } \\
\hline \multicolumn{7}{|c|}{ Economical Field } \\
\hline Weight & \multicolumn{2}{|l|}{ Indicator / Moderating factor } & \multicolumn{2}{|c|}{ Weight value range } & \multicolumn{2}{|l|}{ Indicator value } \\
\hline 1 & Financial payback & Return at the end of the cycle (5-7 years). & \multicolumn{2}{|l|}{ Occurs (1) } & $\begin{array}{l}\text { Factor } \\
\text { Longer than } 5 \text { years }(0)\end{array}$ & 1 \\
\hline 1 & Alternative income source & $\begin{array}{l}\text { Possibility of producers access to silvicultural area which } \\
\text { is highly profitable and restricted to huge capital. }\end{array}$ & \multicolumn{2}{|l|}{ Yes (1) } & \multicolumn{2}{|l|}{1} \\
\hline 1 & Decrease of food offer & Food price increases. & \multicolumn{2}{|l|}{ Yes (-1) } & \multicolumn{2}{|l|}{-1} \\
\hline 1 & Production value & $\begin{array}{l}\text { The wood increases its value due to the need for wood } \\
\text { of Cellulose and Paper factories. }\end{array}$ & \multicolumn{2}{|c|}{ Increases value (2) } & 2 & \\
\hline 1 & Production costs & Production and maintenance costs are paid by incentive & Decreases & (1) & 1 & \\
\hline
\end{tabular}




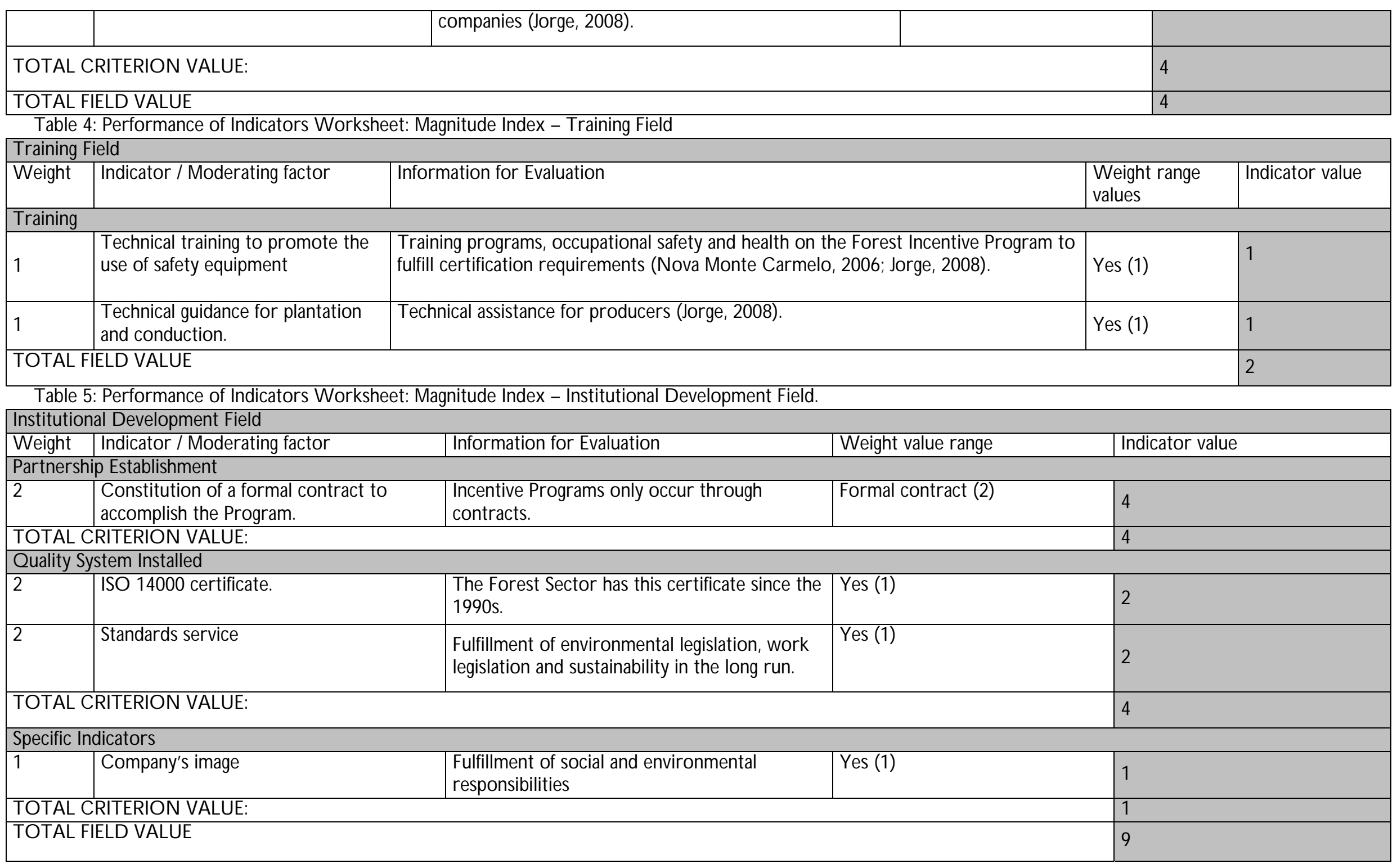


With the data on hands, the methodology recommends an analysis of the program's performance by field (Figures 3 and 4) in order to identify which fields had worse performance and then, direct the recommendation to increase the effectiveness of impact management. In the present case, the most problematic fields are: Social (4); Training (2) and Economical (3). On the contrary, the Institutional Development scope, which refers to direct impact of the Program on the incentive company, had a better performance (9).This result shows advantages for companies in the "Incentive Program based on Eucalyptus Monoculture". The performance of Environmental scope was considered low and positive (12), because though it is a monoculture, it showed some advantages when compared to agriculture.

To calculate the General Impact Index the previous values were applied in the formula and obtained 6,2 points for the "Forest Incentive Program based on Eucalyptus Monoculture". This value corresponds to quadrant 5 on the Impact Matrix which suggests "management with restrictions" for a better performance of this program (Figures 3 and 5).

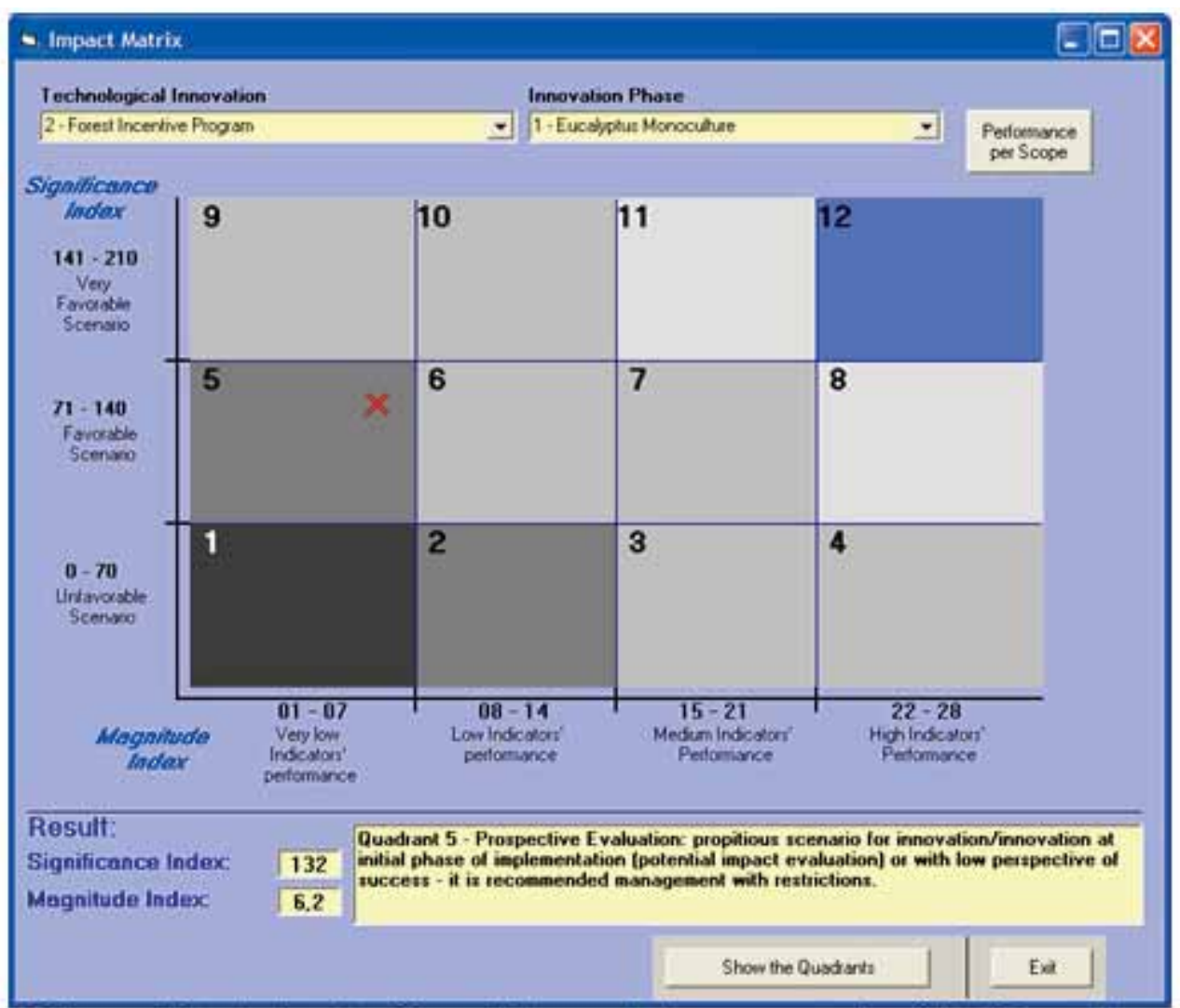

Figure 3: Impact Matrix showing General Impact Index - case study of the "Forest Incentive Program based on Eucalyptus Monoculture". 


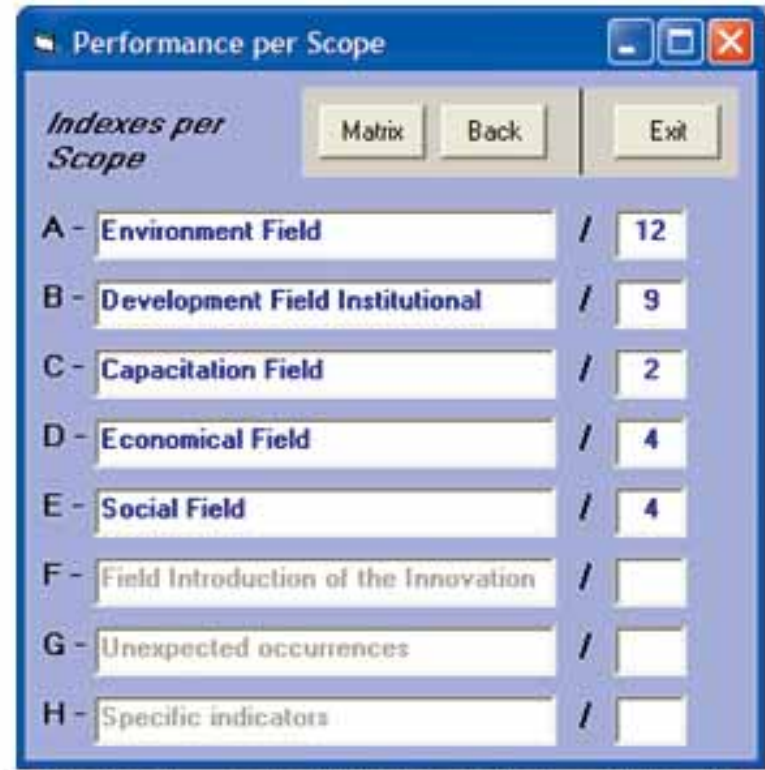

Figure 4: Performance per Scope - case study of the "Forest Incentive Program based on Eucalyptus Monoculture".
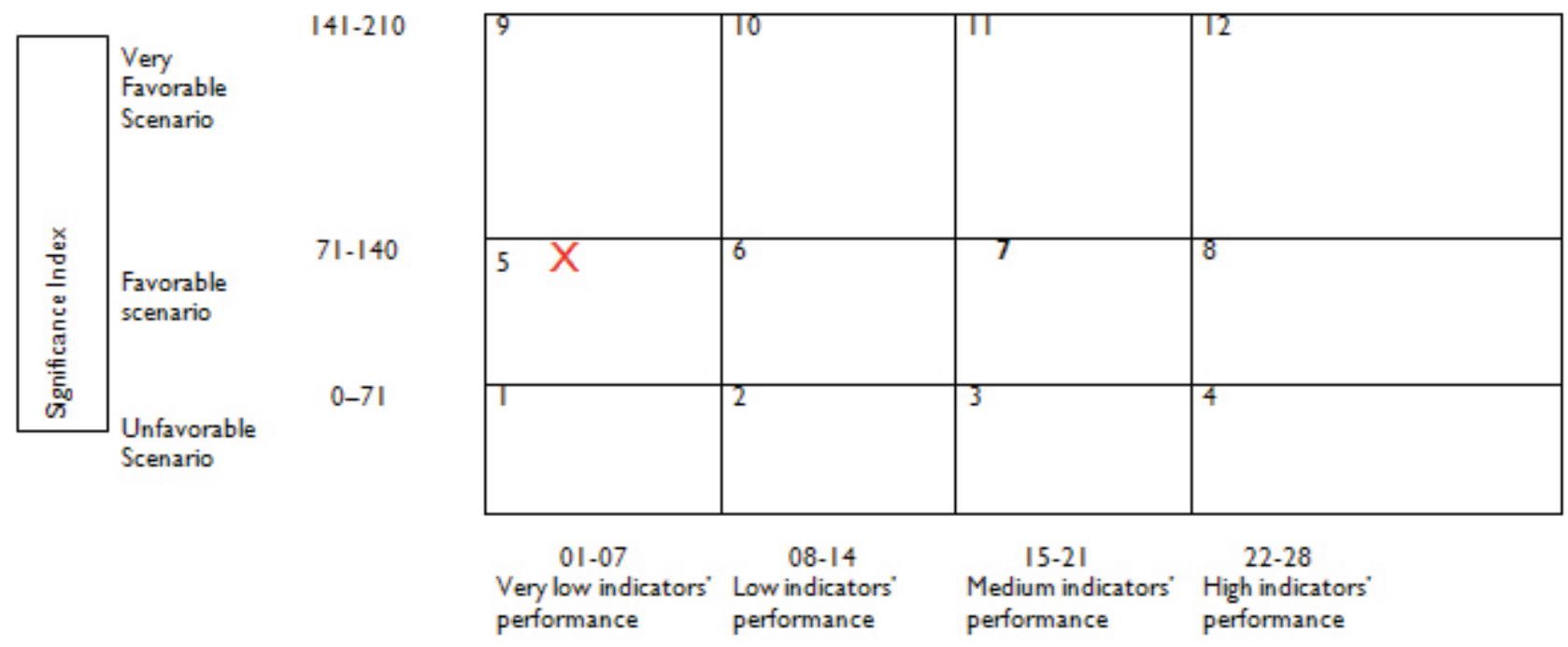

Magnitude Index

Figure 5: Impact Matrix: final phase of Impact Assessment of Inova-tec System. The Impact Matrix provides us an overview of the impact and defines how it should be managed. "Xaxis" represents Magnitude Index's class and " $y$-axis" represents Significance Index's class.

The performance of the "Forest Incentive Program based on Eucalyptus Monoculture" was classified as follows:

(5) Prospective Evaluation: propitious scenario for innovation/innovation at initial phase of implementation (Potential impact evaluation) or with low perspective of success - it is recommended management with restrictions.

\section{Impact Management: Recommendation List}

Considering not only the evaluation accuracy but also the accuracy in the preparation of a proposal for impact management, 
it is recommended that all process should be carried out in collaboration with specialists to guarantee the accomplishment of the suggestions made at the end of the work, and to ensure the best program performance on all fields where the impact can be perceived.

In order to improve economical impact's performance, the items on incentive contracts must be revised. For example: saplings donation may have a positive economical impact for producers, working as an incentive to improve productive processes.

Company incentives for mixed farming system (agrosilviculture) could bring an income increase, because it could enable multiple use of land, increasing its value. In the same way, it could enable a decrease on pressure for food and therefore, create a positive effect on social impact.

A higher contractual flexibility for species diversification cultivated on the percentage of land designated for producers' use (3-5\%), increasing forest varieties, could diversify the producer's income source. They could cultivate for example, eucalyptus species suitable for other uses as woodwork and carpentry, designed to other sectors like furniture, wood sheet, essential oil extraction, or even to the production of fence posts for the use in the property. Harvesting crop varieties for food production could become an important alternative income source, because the economical payback of wood production is long, between 5 and 7 years after plantation. There are successful experiences of mixed farming systems of eucalyptus with rice, beans, soy and peach palm harvests. Another alternative is an agrosilvipasture system, where the eucalyptus is mixed with brachiaria grass and livestock. Bee breeding for honey production could also be an economical alternative for the property.

As a way to raise property income, training in harvesting and transportation could make more work available for producers' family members.

The impact of the "Forest Incentive Program based on Eucalyptus Monoculture" on environment is economical, social and environmentally very favorable.

Forest companies already have studies testifying that mixed harvest with annual crops or animal breeding (agrosilviculture) does not damage eucalyptus development, which is the most profitable harvest (Scanavaca Júnior, 2008). It is suggested that these companies incentive this practice, as well as, evaluate the impacts of agrosilviculture, taken as a whole.

\section{Final Considerations}

An impact analysis of a program must be carried out aiming at the prediction of potential negative impacts on the environment and society. This kind of analysis enables the use of protective measures on program implementation, aiming to mitigate, or even prevent effects resulting from the identified impacts.

The proposed method inserts variables that enable a less subjective evaluation, allowing quantifying and measuring the impact level based on data and technical information. The characterization of the scope or significance of the impacts also allows determining measures, on the activity implantation, to control or mitigate risks.

The use of a scale of weighing factors provides considerable quality to weighing and clearness to evaluation.

Although impact evaluation involves certain amount of subjectivity, especially concerning agricultural programs, the development of a methodology devoted to impact assessment, with an objective organization of weighing and with a diagnosis of potential impacts on economy, society and environment, can act as a more specific tool on the legitimacy of the evaluation process of forest enterprises.

In the case of the "Forest Incentive Program based on Eucalyptus Monoculture" the Inova-tec System let to conclude that despite the favorable scenario for incentive programs, they will only be efficient if they take into consideration the three scopes of sustainability: environmental, social and economical.

The Forest Sector nearly as a whole has ISO 14000 Certification, which requires the achievement of social inclusion, respect for legislation and sustainability in the long term. In this way, it is recommended a better divulgation of these partnerships' results and a larger debate of the parts involved in order to testify whether the criteria are followed or not.

Periodically, every ten months, a regulatory institution from ISO Certification checks if the company is following the agreement. It is suggested that; apart from confidential data of the company's exclusive use, the general data should be divulgated to legitimate scientific evidences.

In the same way, the update of the forest and agricultural production's census, which dates from 1986, could bring more quality and accuracy to the results of the sector's impacts. 


\section{References}

ABRAF.Anuário estatístico do ABRAF: ano base 2006. Brasília: ABRAF, 2007. 80p.

GUERRA, C. Meio ambiente e trabalho no mundo do eucalipto: $2^{\mathrm{a}}$ ed., Belo Horizonte. SEGRAC: 1995.

JESUS-HITZSCHKY, K. R. E. Impact Assessment System for Technological Innovation -INOVA-tec System. Journal of Technology Management \& Innovation, 2 (2), p. 67-82. 2007.

JORGE, L. Experiências de Sistemas Agroflorestais na Suzano Papel e Celulose. In: Simpósio Interestadual sobre Sistemas Agroflorestais - SAFs. Vitória, 2008. Retrieved from the Web 07/07/08. http://www.cedagro.org.br.

KOOPMANS, J.Além do Eucalipto - o papel do Extremo Sul. $2^{\mathrm{a}}$ ed. Salvador:Teixeira de Freitas: DDH - Centro de Defesa dos Direitos Humanos, 2006.

LEÃO, R. M.A floresta e o homem. IPEF (Instituto de Pesquisas e Estudos Florestais), Piracicaba, 2000. 434p.

LEITEe, N. B. Eucalipto com ciência, plantio consciente. In: BERTOLA,A. Eucalipto - 100 anos de Brasil:"Falem mal, mas continuem falando de mim!'. [s.d.]

LIMA, W. P. Impacto ambiental do eucalipto. 2ed. São Paulo: Editora da Universidade de São Paulo, 1993. 30 Ip.

Nova Monte Carmelo S/A - Reflorestamento e Agropecuária (Satipel Florestal). Resumo público de certificação FSC Programa SmartWood. Estrela do Sul, 2006. 39p.

NOVAIS, R. F.; Barros, N. F; Costa, L. M. da.Aspectos nutricionais e ambientais do eucalipto. Revista Brasileira de Silvicultura, v. I8, n. 68, p. 10-17, 1996.

OLIVEIRA, A. D.; Scolforo, J. R. S.; Silveira,V. de P.Análise de um sistema agro-silvo-pastoril implantado em região do Cerrado. Ciência Florestal, Santa Maria, v. I0, n. I, pI - 19, 2000.

OLIVEIRA, P. R. S. Diagnóstico e indicadores de sustentabilidade em fomento florestal no Estado do Espírito Santo. 2003. 127p. Dissertação (Mestrado em Ciência Florestal) - Universidade Federal de Viçosa,Viçosa, 2003.

POGGIANI, F. Ciclagem de nutrientes em ecossistemas de plantações florestais de Eucalyptus e Pinus, implicações silviculturais. 1985, 2IIp. Tese Livre-Docência. Escola Superior de
Agricultura "Luiz de Queiroz" da Universidade de São Paulo, Piracicaba, 1985.

POGGIANI, F. Ciclo de nutrientes e produtividade de florestas implantadas. São Paulo: Revista Silvicultura, v. I, n,3, p.45-48, 1976.

POGGIANI, F.; SCHUMACHEKER, M. V. Atmospheric inputs compared with nutrient removed by harvesting from Eucalyptus plantation: implications for sustainability. In: "I UFRO Conference on Silviculture an d improvement of Eucalipts". Proceedings. Salvador, 1997. Colombo: Embrapa : Centro Nacional de Pesquisa de Floresta. v. 4, p.68-74, 1997.

SBS (SOCIEDADE BRASILEIRA DE SILVICULTURA). O Setor Florestal Brasileiro: Estatísticas. Retrieved from the Web 23/07/08. http://www.sbs.org.br/estatisticas.pdf.

SCANAVACA Júnior, L. Avaliação de indicadores sociais, econômicos e ambientais em SAFs.Vitória, 2008. Retrieved from the Web 07/07/08. http://www.sbs.org.br/estatisticas.pdf.

TSUKAMOTO Filho, A. Fixação de carbono em um sistema agroflorestal com eucalipto na Região do Cerrado de Minas Gerais. 2003. 99p. Tese Doutorado. Universidade Federal de Viçosa,Viçosa, 2003.

VIEIRA, L.; Cader, R. A política ambiental do Brasil ontem e hoje. Revista Eco 21. Retrieved from the Web 21/08/07. http://www.eco2I.com.br/textos/textos.asp?ID=|60I.

\section{About Author}

Katia Regina Evaristo de Jesus-Hitzschky was born in São Paulo, Brazil on April 30th 1973. She received her B.Sc. in Biology at Universidade Federal de São Carlos in 1996. Thereafter, she finished the graduate course she started at Universidade de São Paulo in the Biotechnology Post Graduate Program. She got her master degree in Technological Economy in 1999, then she started her PhD in the same program and worked in Microorganism Molecular Genetics. She started to work in the biosafety area in $200 \mathrm{I}$ when she entered in environmental research unit at the Brazilian Agricultural Research Agency (Embrapa). She focused her research on the environmental impact of GMOs. Currently, she is working in the research line of technology impact assessment in several subjects, such as technology innovation and nanotechnology, and she is keeping her original goal of evaluating transgenic crops.

Ana Paula Carraro was born in Leme, Brazil, on September 30, 
1981. She is Forest Engineer for UNESP (Universidade Estadual Paulista Júlio de Mesquita Filho) in 2007.

Laerte Scanavaca Júnior was born in Piracicaba, Brazil, September 27, I96I. He is Forest Engineer (1990) and Master in Forest Sciences (200I) for ESALQ (Escola Superior de Agricultura Luiz de Queiroz) of the University of São Paulo (USP). He worked four years in IPEF (Instituto de Pesquisas e Estudos Florestais) in the area of Seeds and Genetic Improvement, later one year as researcher of a company that makes reforestation in the Amazonian (Camargo Corrêa) and one more year as researcher of GUARANY, company that develops and it markets linked equipments to the Forest Section. $\mathrm{He}$ is in Embrapa six years ago and he is working with the environment and with SAFs (Sistemas Agroflorestais). 